\title{
ECO-MANAGEMENT AND SUSTAINABILITY ASPECTS OF INNOVATIVE DEVELOPMENT STRATEGIES
}

\author{
Author(s): \\ M. Czikkely ${ }^{1}-$ Cs. Fogarassy ${ }^{2}$
}

\section{Affiliation:}

${ }^{1}$ Assistant lecturer, Climate Change Economics Research Centre, Faculty of Economics and Social Sciences,

Szent István University, Gödöllö

${ }^{2}$ Associate professor, Head of Centre, Climate Change Economics Research Centre,

Faculty of Economics and Social Sciences, Szent István University, Gödöllő

Email address:

fogarassy.csaba@gtk.szie.hu; czikkely.marton@gtk.szie.hu

\begin{abstract}
During the post-industrial revolutions, until the 20th century. By the last third of the 20th century, two basic directions of industrial development could be defined. One preferred to invest in local resources, with the help of state-owned companies, while the other favored industrial innovation in the export of capital by national companies. The two directions of industrial development were in some ways similar. Ecological sustainability aspects have not been taken into account during the development and operation of the technology. From this, we can see that ecomanagement as the management of eco-conscious companies in terms of environmental management was not a preferred aspect at that time. In the last third of the 20th century, environmental problems and the social and economic effects of pollution had also become globalize and were becoming increasingly important aspects of corporate governance. This is also due to the fact that the environmental spread of contaminants did not stop within the boundaries of a particular company, but because of the environmental conditions, they showed increasing risks to human health and the environment. As a result, companies have increasingly focused on environmental and human aspects, avoiding negative externalities and risks.
\end{abstract}

\section{Keywords}

Sustainability, eco-management, economic transformation, theoretical background, enterprise strategy

\section{Ecological aspects of each corporate behaviors}

The issue of sustainability is now being raised not only at the ecological level but also at the economic and social level. This is what the Sustainable Development Goals (SDG) Framework suggests. Most target groups integrate not only ecological but socio-economic aspects. The global and local challenges of the 21 st century, the escalating environmental crisis, problems arising from urbanization processes, overpopulation and changing economic conditions all reinforce the need for integrated thinking.

The strategy of municipalities and companies must necessarily focus on local responses to the challenges, as the economic and environmental interpretation of sustainability requires [1].

The concept of sustainable environmental management is widespread, which takes the form of four main corporate behaviors (depending on how they respond to emerging environmental problems) $[1,2]$.

The following breakdown of behaviors is representative of the attitude of individual companies to the issue of ecological and economic sustainability [2].

One of the main types where companies neglect the environmental impact, in part or in full. Nowadays, this type of corporate behavior is typical only in developing countries, but fortunately less and less. The main problem with this behavior is that it takes into account not only environmental and human risk aspects but also the tangible manifestations of indirect policy regulation following possible contamination [3]. Where companies were fined by environmental 
measures for pollution or pollution, they could be covered by the profits from the sale of cheaper technology products. A significant problem has also been that in many cases, companies have undertaken to pay for pollution-related regulations rather than for technological innovation and to finance costly environmental investments [4].

Contrary to the behavior formulated in the first point, most companies have sought to mitigate environmental problems in some way, and to manage and eliminate risks. Companies were also encouraged by indirect policy regulations, and it should not be overlooked that the personal attitudes and environmental sensitivities of those responsible for corporate governance also contributed to solving the problems. Of course, for companies with this kind of behaviors, it meant technological innovation, financing environmental remediation, which led to a significant increase in expenditure [5]. Nowadays, companies that exhibit such behavior also have a supportive rebate system that allows countries to provide, for example, preferential interest-subsidized loan schemes and tax breaks [4,5].

The third type of company includes those companies that not only focus on the elimination of already existing environmental problems but also on the prevention of pollution. A complete set of tools is available for this purpose, such as waste water collection and treatment, as well as purification of waste water from technological operations. This is still available today, but can also be linked to the Life Cycle Analysis (LCA) of manufactured products and the economic development of production technology [6]. In the latter, circular economic aspects are also emerging. This involves technology development that results in reduced or zero waste production and focuses on recycling primary and secondary raw materials, including them in the input side of the production process.

The fourth form of corporate behavior is the demand of the 21 st century [7]. The use of clean technologies is ultimately the final stage in the process of the third behavior described above. Thanks to innovation focused on pollution prevention, the goal is to develop clean technology, that is to say, environmental aspects must be taken into account at all stages of production and the necessary improvements must be made. Nowadays, the zerocarbon emission, the zero-waste competition is pointing in that direction $[7,8]$. Many large Hungarian companies, such as Richter Gedeon and Egis companies, the two giants of the pharmaceutical industries, produce an environmental report each year that assesses the operation of the technologies used in the company from an environmental and economic point of view [8].

\section{Appearances of industrial ecosystems on enterprise level}

The spread of the concept of green industry or industrial ecology shows progress not only in thinking but also in practical management behaviors. Industrial ecology reconciles social, economic and environmental aspects, focusing on environmental economic criteria. This may be interpreted as meaning that the analysis of technological industrial systems is not done in isolation but in a systemic perspective [9]. The sustainability of industrial technologies is usually analyzed on a matrix basis. On both the input and output sides, we focus on optimizing material and energy balances. Optimization emphasizes the coordinated operation of resources, capital, and energy, complemented by systemic analysis $[8,9]$.

Companies that use industrial eco-systems integrate environmental costs into costs, accounting and prices. At the same time, it can be seen the positive environmental impact of all this [1,3,9]. When analyzing the operation of companies using industrial ecosystems, it is important to emphasize and the terms 'triple end' and 'double profit'. The triple end result is the expectation that social and environmental outcomes are reflected in the traditional profitoriented system. The dual-profit approach can be interpreted as meaning that companies must not only focus on cost reduction and sustainable competitiveness but also aim to increase environmental efficiency and improve social performance [9].

Corporate behavior must also reflect that the company's operations favor eco-innovations in the production of the product, which requires a change in company strategy and an examination of environmental competitiveness $[9,10]$. The regulatory environment required for this is also assisted by the International Organization for Standardization, through the introduction and continuous improvement of its environmental management standards system. An increasing number of companies are adopting the ISO 14000 environmental standard family to effectively improve their environmental performance and sustainability [10]. The standard includes principles, applicable norms, and recommended decision-making mechanisms in the areas of environmental management, auditing, benchmarking, product lifecycle analysis and Circular Economic Value (CEV) calculations for all environmental 
elements, and to reduce and reset the pressures and pollutants to which they are exposed [10].

The pressures of society, the emergence, and expansion of social demands, and the shift in consumer preferences should also be mentioned as causes of changes in corporate attitudes and attitudes. If a company wants to remain competitive in the market, it must take into account that consumer demand for products made with environmentally friendly technology is increasing, as the environmental attitudes of society are constantly changing and improving $[1,2,9]$. In the development of personal attitudes, special attention is given to environmental education, its connection with sustainability and environmental awareness (a practical example of this is the Sustainability Student Days held every year by high school institutions, as well as the Carbon Free Day - Bike Program).

\section{Innovative enterprise attitude in the future smart cities}

Operational objective 11 of the UN Framework for Sustainable Development aims at mapping the relationship between settlements and society in general and formulates proposals for solutions such as sustainable urban planning and regional spatial planning, and addressing the negative impact of environmental disasters on settlements. Nowadays this target group has been supplemented with the strategic development program of smart cities, which has taken the planning, infrastructure development and coordination of social aspects to a new level. In the following, in addition to describing the urbanization roles of smart cities, we also discuss how this is related to social welfare aspects and changes in population preferences.

The issue of smart cities is one of the latest research areas in social and environmental science. The concept of the smart city means linking the future directions of urban development with priority areas such as ecological sustainability and optimization of urban water management, technological (IT) modernization and social aspects of urban development [10]. Urban development concepts are particularly important issues in terms of urbanization. 21 st Century changes in modern metropolitan areas must necessarily be guided by the development ideas that follow. Today, technological advances, industrial modernizations, environmental awareness, the use of renewable and alternative energy sources cannot be ignored, nor do they have significant geographical, sociological implications [11]. The future lies in smart cities, that is, modern, liveable cities, where continuous technological developments (e.g. wastewater treatment, drinking water treatment technological developments), environmental (ecological) sustainability are brought into line with social needs, job creation, social welfare system development, with the modernization of transport, the relevant legal and normative system [10,11].

The study of Angelidou [12] also touches on the most important historical factors that have led to the emergence of smart cities today (and to some extent future ones). As a result of the technological explosion that has begun with the Industrial Revolution and has continued ever since urban development concepts always aim to build the city of the future by bringing high-tech technologies of the time into everyday life. After World War II, with the use of the state-of-the-art technology available at the time, the livelihood of major cities became a major issue. The prosperity of the individual, communities and urban populations and the provision of better living conditions have come to the fore. The 1960s saw the emergence of the "electronic urbanization" trend $[11,12]$, the telecommunication model resulting from the development of information systems. It focused on urban work and telework, and on the modernization of services and education [12].

An important element of smart city development is monitoring the changes in society $[12,13]$. All segments of the technological and information revolution of the $21^{\text {st }}$ century are closely linked and have an impact on society. Today, the knowledge and innovation economy is gaining ground. With the advancement of the knowledge economy and the emergence of the information society, the integration of IT systems into the economic life of smart cities should be promoted [13]. More and more industrial technology processes are controlled by software, taking over the human role, but human resources are essential for managing and developing software. In other words, in the smart cities of the future, technological and IT innovation must be encouraged, but education, vocational training, and tertiary education must also be developed (here is where the impact of technological innovation on society becomes visible) $[13,14]$.

Another particularly important aspect of smart city development is the issue of environmental protection and environmental sustainability [14]. This approach combines the social and the "green" viewpoints, as smart and green developments and green technologies need to be approached in terms of social necessity and utility. Another important question is how technically this can be done [15]. The question of the relationship between sustainable development and technical 
development and the possibility of improving the quality of human life (such as "smart environment", "smart energy") arises [16]. In summary, the subsystems of smart cities can be incorporated from an engineering point of view, through environmental sustainability, into social aspects [17].

\section{Conclusion}

Modern corporate governance needs to be in line with environmental and economic sustainability, so behaviors must reflect new eco-economic considerations. Corporate innovation strategies and production processes must be designed in such a way that efficiency must be kept in mind throughout the development process, which not only applies to product production but also incorporates the ecological "green" aspect. In conclusion, in my study, I wanted to present a research area that sheds new light on innovation developments. Municipal modernizations, smart cities, sustainable corporate governance are all integral parts of the future urban management system.

\section{References}

[1] SIMAI M. 2016: A harmadik évezred nyitánya: A zöld fejlődés esélyei és a globális kockázatok. (The opening of 21th century: Options of green development and global risks). Budapest: Corvina Kiadó Kft. 374 p.

[2] VILLÁNYI L., VASA L. (ed.) 2007: Agrárgazdaságtan. (Agricultural economy) Budapest: Szaktudás Kiadó Ház Publisher 215 p.

[3] SCHALTEGGER, S., F. LÜDEKE-FREUND, HANSEN, E. 2012: Business Cases for Sustainability: The Role of Business Model Innovation for Corporate Sustainability. International Journal of Innovation and Sustainable Development, 6(2), 95-119.

[4] SCHALTEGGER, S., E. HANSEN, \& LÜDEKE-FREUND, F. 2016: Business Models for Sustainability: Origins, Present Research, and Future Avenues. Organization and Environment, 29(1), 3-10. [5] SARKAR C., WEBSTER C. 2017: Urban environments and human health: current trends and future directions. Current Opinion in Environmental Sustainability $25: 33-44$. p.

[6] CORRADO S., ARDENTE F., SALA S., SOUTER E. 2017: Modelling of food loss within life cycle assessment: From current practice towards a systematision. Journal of Cleaner Production 140. pp. 847-859.
[7] FOGARASSY CS., KOVÁCS A. 2016: The cost-benefit relations of the future environmental related developments strategies in the Hungarian energy sector. YBL Journal of Built Environment 4 (1): 33-49 p.

[8] EUROPEAN ENVIRONMENT AGENCY 2014: National adaptation policy processes in European countries 2014. Luxembourg: Publications Office of the European Union. 130 p.

[9] WORLD BUSINESS COUNCIL FOR SUSTAINABLE DEVELOPMENT 2017: 8 Business Cases for The Circular Economy. World Business Council for Sustainable Development, Geneva, Switzerland.

[10] BLADES L., MORGAN K., DOUGLAS R., GLOVERA S., De ROSA M., CROMIEA T., SMYTH B. 2017: Circular Biogas-Based Economy in a Rural Agricultural Setting. 1st International Conference on Sustainable Energy and Resource Use in Food Chains, ICSEF 2017, 19-20 April 2017, Berkshire, UK. Energy Procedia 123: 89-96 p.

[11] BATTY M., AXHAUSEN K.W., GIANNOTTI F., POZDNOUKHOV A., BAZZANI A., WACHOWICZ M., OUZOUNIS G., PORTUGALI Y. 2012: Smart cities of the future. The European Physical Journal Special Topics 214: 481-518 p.

[12] ANGELIDOU M. 2015: Smart cities: A conjuncture of four forces. Cities 47: 95-106 p.

[13] HUSTON S., RAHIMZAD R., PARSA A. 2015: 'Smart' sustainable urban regeneration: Institutions, quality and financial innovation. Cities 48: 66-75 p.

[14] KÁPOSZTA J. 2016: Regionális összefüggések a vidékgazdaság fejlesztésében (Regional relations in rural development). Studia Mundi - Economica 3 (1): 52-61. p.

[15] NAVARRO C., ROCA-RIU M., FURIÓ S., ESTRADA M. 2015: Designing new models for energy efficiency in urban freight transport for smart cities and its application to the Spanish case. Transportation Research Procedia 12: 314-324 p.

[16] MATTONI B., GUGLIERMETTI F., BISEGNA F. 2015: A multilevel method to assess and design the renovation and integration of smart cities. Sustainable Cities and Society 15: 105-119 p. [17] NEIROTTI P., DE MARCO A., CAGLIANO A.C., MANGANO G., SCORRANO F. 2014: Current trends in smart city initiatives: Some stylised facts. Cities 38: 25-36 p. 